\title{
Correction to: The impact of COVID-19 in the attendance of patients to the otolaryngology clinic: a retrospective review
}

\author{
Kanachai Boonpiraks ${ }^{1}$, Yanin Nawachartkosit ${ }^{1}$ and Dhave Setabutr ${ }^{2 *}$ \\ Correction to: Egypt J Otolaryngol 37, 82 (2021) \\ https://doi.org/10.1186/s43163-021-00147-0
}

Following the publication of the original article [1], the authors identified errors in the Methods and Discussion section. The symbol * has been replaced with Thammasat.

The original article [1] has been corrected.

\author{
Author details \\ ${ }^{1}$ Faculty of Medicine, Thammasat University, Pathum Thani, Thailand. \\ ${ }^{2}$ Department of Otolaryngology, Chulabhorn International College of \\ Medicine, Thammasat University, Thammasat University Hospital, Pathum \\ Thani, Thailand.
}

Published online: 07 September 2021

\section{Reference}

1. Boonpiraks et al (2021) The impact of COVID-19 in the attendance of patients to the otolaryngology clinic: a retrospective review. Egypt J Otolaryngol 37:82. https://doi.org/10.1186/s43163-021-00147-0

* Correspondence: dsetabutr.cicm@gmail.com

${ }^{2}$ Department of Otolaryngology, Chulabhorn International College of Medicine, Thammasat University, Thammasat University Hospital, Pathum

Thani, Thailand

Full list of author information is available at the end of the article

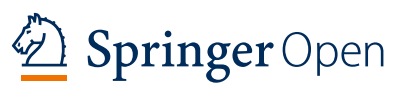

(c) The Author(s). 2021 Open Access This article is licensed under a Creative Commons Attribution 4.0 International License, which permits use, sharing, adaptation, distribution and reproduction in any medium or format, as long as you give appropriate credit to the original author(s) and the source, provide a link to the Creative Commons licence, and indicate if changes were made. The images or other third party material in this article are included in the article's Creative Commons licence, unless indicated otherwise in a credit line to the material. If material is not included in the article's Creative Commons licence and your intended use is not permitted by statutory regulation or exceeds the permitted use, you will need to obtain permission directly from the copyright holder. To view a copy of this licence, visit http://creativecommons.org/licenses/by/4.0/. 